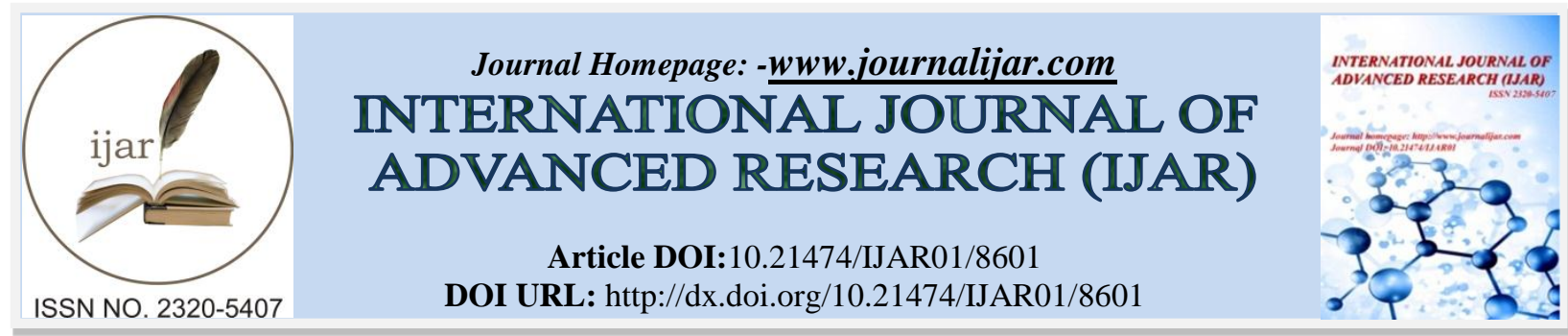

RESEARCH ARTICLE

\title{
IMPLEMENTATION OF PROBLEM BASED LEARNING METHOD IN PKN (CIVIC EDUCATION) COURSE.
}

Suardi.

Creative Media State Polytechnic, Indonesia.

\section{Manuscript Info}

\section{Manuscript History}

Received: 02 January 2018

Final Accepted: 04 February 2019

Published: March 2019

Key words:-

Based, Civic, Education, Learning, and Problem.

\begin{abstract}
This study aims to improve students' ability to express their opinions on PKn (Civic Education) graphic design majors by applying the Problem Based Learning (PBL) model through discussion techniques to form a positive student social attitude as a provision to socialize in the community. This study uses a type of classroom action research (CAR) focused on classroom situations commonly known as classroom action research. PTK is an action research aimed at improving the quality of learning in the classroom. The focus of PTK on students and the teaching and learning processes that occur in the classroom. The main purpose of PTK is to solve problems that occur in the classroom and improve the real activities of lecturers in the development of their profession. Based on the results of research and discussion it can be concluded that the Application of Problem Based Learning models can improve the ability. that is, with indicators formulating problems, being able to ask and answer questions, having critical and logical thinking in analyzing problems, then being able to find relevant information and be able to deduce the results of the presentation.
\end{abstract}

Copy Right, IJAR, 2019,. All rights reserved.

\section{Introduction:-}

Education that is carried out well is the basic framework in building a developed nation. It has become a general opinion that the progress or failure of a nation is influenced by educational factors. The era of globalization as it is now, education is a basic need that cannot be separated from everyday life, because through education Indonesian people are equipped with knowledge and skills to be able to survive and adapt to the times. Article 20 of the Law of 2003, national education serves to develop capabilities and shape the character and civilization of the nation with the aim of developing the potential of students to become qualified human beings with characteristics of faith and devotion to God, noble, healthy, faithful, capable creative, independent, and a democratic, responsible citizen (Law No. 20 of 2003).

Under Law No. 20 of 2003 concerning the National Education System in the preliminary section stated that each educational unit is directed to achieve goals based on the level of growth and development of students. Basically the purpose of education in various levels and arenas of education is the achievement of maturity of functions and structures, both physically and psychologically so that students become adults.

Corresponding Author:-Suardi.

Address:-Creative Media State Polytechnic, Indonesia. 
The importance of the role and purpose of education, so that the government demands to continue to make reforms to achieve a better education system through structuring in various components of education, one of which is through curriculum improvement. The implementation of education in Indonesia is inseparable from the application of a curriculum that must always be adapted to the times.

According to Trianto (2013: 15) explained that the curriculum is any activity carried out by the campus in order to influence students in learning to achieve a goal, can be called a curriculum, including teaching and learning processes, arranging strategies in learning, how to evaluate teaching development programs and the like .

The process of human thinking has evolved, so that in carrying out learning in particular the learning of Pancasila and Citizenship (PKn) Education in all levels of education, especially in the level of senior lecturers, a concept of student intellectual development is required by lecturers. Intellectual elements are derived from the material concepts taught, while the personal and social elements of individuals are derived from the concepts and applications of the material taught in each subject, one of them is PKn.

The ability to think is one of the actualisations of the personal and social elements of the individual obtained from the concepts and applications of the material taught in PKn courses. To grow this attitude in each student, a technique and method is needed in the learning process that can stimulate each individual in opinion. One of them is through group discussions by first giving a certain topic. So that in this study the author raises the theme "Application of Problem Based Learning (PBL) Learning Model through Discussion Techniques to improve the ability to express Mahasisswa's opinion on Learning Citizenship Education."

\section{Research Questions}

Based on this background, a research problem was formulated, namely: Is the application of the Problem Based Learning (PBL) model through discussion techniques able to improve the ability to express student opinions in PKn courses?

\section{Limitation of Research}

In this study, the authors limit the scope of the problem of graphic design majors Creative Media State Polytechnic in Makassar in the odd semester 2017/2018.

\section{Research Objectives}

The purpose of the author to do this research is as follows.

1. To improve students' ability to express opinions on PKn subjects in graphic design with the application of the Problem Based Learning (PBL) model through discussion techniques

2. Through the application of the Problem Based Learning (PBL) model through discussion techniques a positive student social attitude is formed as a provision to socialize in the community.

\section{Research Method:-}

This study uses a type of classroom action research (CAR) focused on classroom situations commonly known as classroom action research. PTK is an action research aimed at improving the quality of learning in the classroom. The focus of PTK on students and the teaching and learning processes that occur in the classroom. The main purpose of PTK is to solve problems that occur in class and improve the real activities of lecturers in the development of their profession (Kunandar, 2010: 45).

In accordance with Kunandar's opinion, Sanjaya (2010: 32) states that Classroom Action Research (CAR) is one of the efforts made by lecturers to improve the quality, roles and responsibilities of lecturers in managing learning. Through PTK, lecturers can improve their performance continuously by doing self-reflection namely analyzing efforts, finding weaknesses in the learning process that they do, then planning it in the learning process in accordance with the learning program that they have compiled and ending with reflection.

Meanwhile, Arikunto (2011: 16) explains that in general there are four stages that are passed, namely:

1. Planning,

2. Implementation,

3. Observation, and

4. Reflection. 
This cycle does not only take place one time, but can be carried out several times until the learning objectives are reached. The flow of action in this class action research is shown in the figure

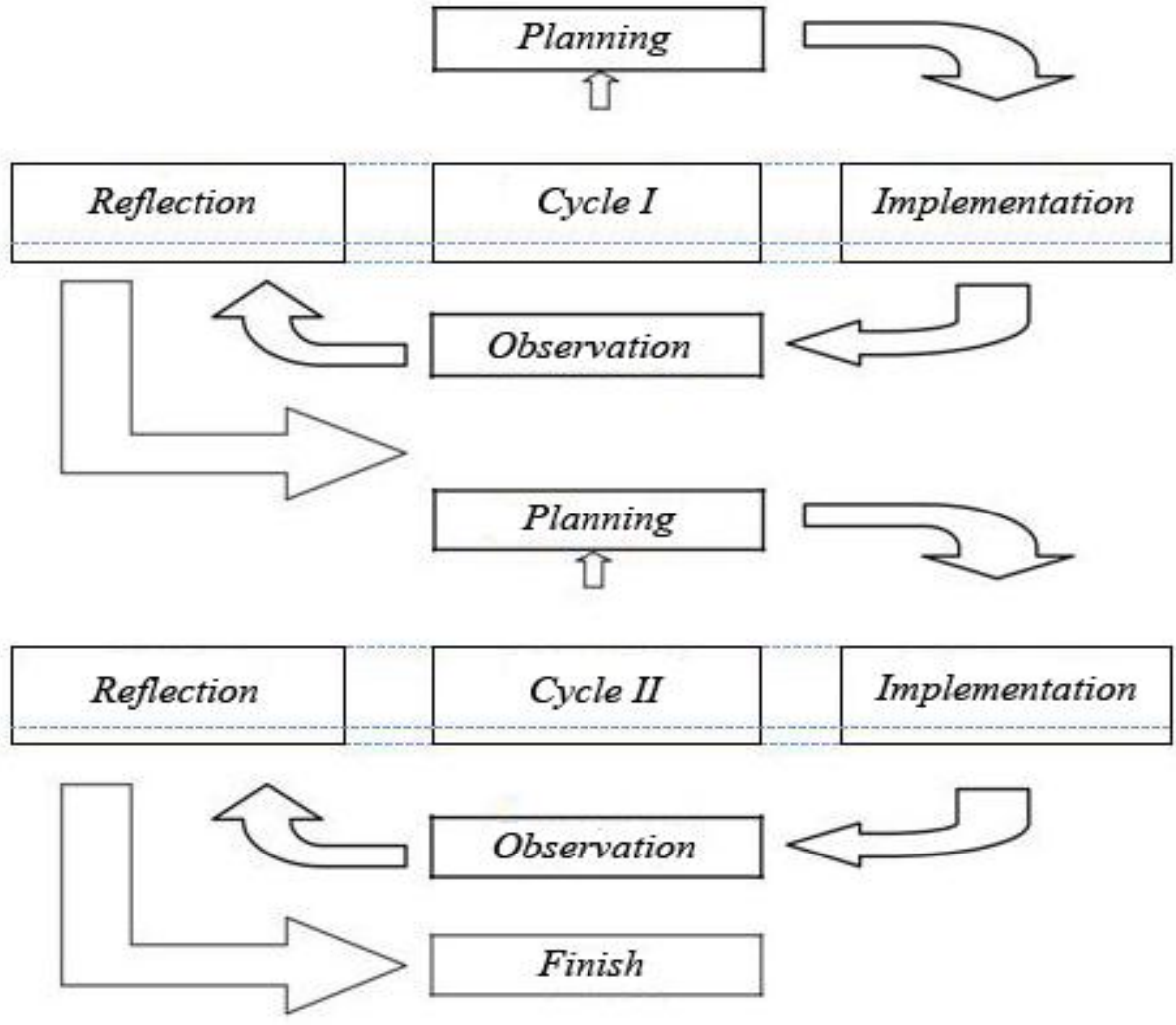

Image 3.1:-Class Action Research Flow

By: Arikunto (2011: 16)

\section{Research Results And Discussion:-}

Application of Problem Based Learning to Improve the Ability to Issue Opinions at Graphic Design Study Programs of Creative Media State Polytechnic in Makassar

The research into the implementation of Problem Based Learning in improving the ability to issue opinions in Graphic Design Study Program of the Creative Media State of Makassar PSDD was carried out in three stages, namely Problem Based Learning planning, Problem Based Learning learning process, and Problem Based Learning. For more details, it will be discussed as follows:

\section{Learning Planning increases ability to express opinions}

The learning plan is a class activity plan designed by lecturers in the field of study which contains a step-by-step scenario of what the lecturer does to students in the learning process in relation to the topic to be studied. Planning is the most important component and plays a very important role to be able to carry out learning well and effectively, creating conducive classes for teaching and learning activities in order to encourage students to actively and easily master a number of material contained in the curriculum. Problem Based Learning learning planning improves the ability to issue opinions starting on April 15, 2018. Before carrying out the learning process the researcher coordinates then asks about learning tools such as syllabus, lesson plans, and student worksheets, as well as what lecturers need to prepare before applying the Problem Based Learning model After that the researcher interviewed the lecturer related to the learning process that will be carried out later.

RPP for PBL Model is the same as other learning models, only in emphasizing critical thinking skills made so that students become active emphasized when the core activity process is $5 \mathrm{M}$ (Observing, Questioning, Collecting data, Associating, and communicating). To establish the ability to issue opinions is created during the core activities where students ask questions and discuss. 
In RPP students are trained to think critically by the lecturer seen in the steps of the student in the questioning process, namely students seek and explore questions themselves that can be used as material for discussion by referring to the predetermined title. students formulate a problem that includes the duties and authority of state institutions, articles governing the institutions of the State itself, then institutional relations with each other, and about a positive attitude towards the administration of the government system in Indonesia. The formulation of the student makes in the student worksheet where students have been able to formulate a problem with the title determined by the lecturer.

Able to express opinions, ask questions and answer questions

This activity can be seen in the process of communicating, namely students express their opinions with questions and answers during the presentation, showing how active students to ask questions and explore knowledge that they do not know. Furthermore, in exploring students' thinking skills to see life outside there can be seen in the second meeting of material on Positive Attitudes towards the Indonesian Government System, students outlined a positive attitude about how Indonesia can now do as students see the current state government system.

\section{Having a critical and logical thinking in analyzing arguments}

This activity is seen in student activities during the presentation, namely in communicating activities, namely students argue or express their opinions in accordance with the thoughts of other students in this case, namely logical. then students are critical in this case, namely students have the skills to find the source of information that is in the questions that have been given. That is, students can search for answers or answer questions with the right information.

\section{Search for relevant information}

This activity is to collect data by searching for relevant information in accordance with the facts and facts as stated in the lesson plan, namely using PKn textbooks, UU. No. 20 of 2009, the official website of the state web agency, and the 1945 Constitution.

\section{Able to conclude}

In this activity, it was seen in the closing event where the students concluded the results of the presentation that had been read which were then linked to the answers to the questions and answers. Then students are asked to identify positive attitudes towards the Indonesian government system in various environments by drawing conclusions about the right attitude related to government issues so that students can explore their thinking skills by linking life outside.

\section{Implementation of Learning Model Problem Based Learning}

Before the implementation of the Problem Based Learning model, students of Graphic Design majors in class 10 A, there were already some students who were able to express their opinions and questions and answers about behavior towards Pancasila values in people's lives, family, school, and relationships, so that students had already no stranger to PBL learning.

Implementation of the Problem Based Learning Model Improves the ability to issue opinions

The ability to express opinions is created when PBL learning activities take place. Elements of the ability to issue opinions contained in the Problem Based Learning model for learning Citizenship Education include:

\section{Open to the opinions of others}

Being open to other people's opinions means accepting the opinions of others and all students are given the opportunity by the lecturer to argue without discrimination. Judging from the way students receive all opinions expressed by friends without blame. Be open to the opinions of others seen during discussion and presentation activities. students who argue and provide solutions to problems presented to groups are given the freedom and other students can accept the opinions conveyed written in advance in the paper then later it will be concluded to be the right solution. Unselfish about his own opinion. the lecturer accepts any opinions raised by his students without distinguishing the status and intelligence of his students.

\section{Respecting the opinions of others}

Associate students 10 A Graphic design in appreciating the opinions of others is seen during discussions and presentations in front. If there is a student who expresses his opinion, then other students will listen until it is 
finished, then if the opinion of one student with another student is different then what will be done is not to blame the opinion of the friend but to accommodate the opinion by noting anyone who argues and then drawn a conclusion right. As the interview with Rahma and Faradilla on April 29 2018. They said that: "Attitude respects the opinions of others, namely if there is one of our friends who has a different opinion, we are discussed together together then our different opinions are combined into one".

\section{Working Together in Groups to Produce a Decision.}

The attitude of students working together in groups has emerged. Judging from the way they divide the group assignments so that everyone gets along and no one just goes along with it. For this matter there are also groups that only a few work. Suppose that students share assignments for the problems discussed there are 5 problems and each student should be able to work on one problem, but because there are students who still do not understand about the problem finally given to students who already understand the problem.

\section{Freedom of Opinion}

Free of opinion and respect for freedom is an absolute thing that every student needs to have when students ask questions or express opinions in learning. One characteristic of democracy is the courage of students to express their opinions and be able to respect freedom, but freedom in accordance with the rules. When students in the class have been taught to express opinions, it is hoped that students are able to apply freedom of opinion both in the environment and outside the environment.

\section{Problem Based Learning Assessment Improves the Ability to Issue Opinions at the PSDD Makassar Creative Media State Polytechnic}

Based on the results of the interview on April 15, 2018 that the assessment of learning models Problem Based Learning increases the ability to issue opinions when the discussion takes place and during the presentation. Assessment of the Problem Based Learning Model enhances the ability to issue opinions which consists of two assessments, namely individual assessment and group assessment. Individual assessments are seen when students are discussing. Civics lecturers pay attention to how students work together in their groups, activeness in groups, and create a democratic attitude by appreciating the opinions of friends so that the implementation of the Problem Based Learning model can work well. As mentioned before the lecturer gives an award for students who have been active and critical in the teaching and learning process, both in asking, arguing, giving refutation or suggestions for other groups or students. This method makes some students become enthusiastic and interested in the material being studied.

In this presentation the researcher assessed the ability to issue student opinions when answering questions. Assessment carried out for critical thinking skills is seen in the assessment of students on aspects of problem formulation, then learning resources, as well as group activeness in arguing according to facts and logically. While the assessment carried out to improve the ability to issue opinions is seen from group collaboration, then how to respect the opinions of others, and be polite when expressing opinions seen from the sentence used. Many of the PSDD Creative Media State Polytechnic students still answer questions by using books only, but there are also some who answer questions by linking life around, for example about government policies.

\section{Conclusion:-}

Based on the results of the research and discussion it can be concluded that The application of the Problem Based Learning model enhances the ability. Expressing opinions is manifested in the activities of lecturers in planning, namely by developing aspects of critical thinking skills, namely by indicators formulating problems, being able to ask and answer questions, having critical and logical thinking in analyzing problems, then being able to find relevant information and able to conclude the presentation results. The most critical attitude shown by 10th grade students in learning lies in student activities when students are able to ask questions and answer questions raised by other students in their presentations related to the facts in the field and logically in accordance with the thoughts of other students. The questions asked are able to be answered by considering facts and logical answers. Logical in this case students who have answered questions have thoughts that are in line with other students' thoughts or can be accepted by other friends. Seen in the activity when the questions and answers from the questions and answers submitted by students.

The democratic attitude of students who emerge in learning with the Problem Based Learning model in class $10 \mathrm{~A}$ is open to the opinions of others, respecting the opinions of others, working together or coordinating to produce a 
decision, and freedom of speech. But in this case the most prominent democratic attitude of students is by collaborating in groups. From the democratic attitudes found in student behavior when discussing in value, it strongly supports student learning activities. The democratic attitude of students arises when students divide assignments for members very fairly, then in arguing in groups do not arbitrarily blame the opinions of others.

Assessments carried out in the application of the Problem Based Learning model are carried out during discussion and presentation activities. In the presentation the lecturer assesses the ability to express student opinions when answering questions. Assessment carried out for critical thinking skills is seen in the assessment of students on aspects of problem formulation, then learning resources, as well as group activeness in arguing according to facts and logically. While the assessment carried out to improve democratic attitudes seen from group collaboration seen from students having a fair attitude in dividing tasks, can cooperate in producing a final decision. Then how to respect the opinions of others by listening to each opinion delivered without blame, and polite when expressing opinions seen from the sentence used.

Constraints in implementing the Problem Based Learning model are seen from the two constraints that are created, namely the constraints that apply namely the lecturer and the constraints of support, namely students. The constraints of the lecturer in implementing the PBL model are in terms of classroom management, especially active learning outside the classroom to support critical thinking with real life and the presentation of student presentations over an action or reprimand for students who talk to their side friends, while constraints arise from students when applying the Problem Based Learning model increases the ability to express opinions namely students. Located in the ability of students to ask is still monotonous. Seen in the student activities only 15 people asked from 29 students in the class. 